\title{
FUZZY-LOGIC BASED SELF-TUNING PI CONTROLLER FOR HIGH-PERFORMANCE VECTOR CONTROLLED INDUCTION MOTOR FED BY PV-GENERATOR
}

\author{
Ahmed M. Kassem ${ }^{1}$ and Ali M.Yousef ${ }^{2}$ \\ ${ }^{1}$ Control Technology Dep., Industrial Education College, Beni-Suef \\ University, Egypt, Email: kassem_ahmed53@hotmail.com \\ ${ }^{2}$ Electrical Engineering Dep., Faculty of Engineering, Assiut \\ University, Egypt, Email: drali yousef@yahoo.com
}

(Received April 14, 2012 Accepted April 26, 2012)

In this paper, speed control of an induction motor (IM) fed by a photovoltaic $(P V)$ generator based on a direct proportional and integral controller and an adaptive fuzzy logic controller (AFLC) is presented. Also In this study, it is proposed that the PV output voltage is varies between certain cut in and cut off values that to extract maximum power during different solar irradiation values instead of operating the motor with constant voltage. To decrease the system cost, it is proposed that the system does not contain storage batteries and there is no need for DC/DC converter where, variable voltage of $P V$ generator is considered. The motor speed is controlled to track a certain reference values using the proposed controller. In addition, an efficient vector controller that can achieve high accuracy and a fast dynamic response of the induction machine is presented. Also, In order to validate the effectiveness of the proposed adaptive fuzzy PI (AFPI) controller scheme, the performance of the induction motor with the proposed controller was compared with classical PI controller. Obtained simulation results show that accurate tracking performance of the induction motor is achieved with variations of both PV generator output voltage and the load torque.

KEYWORD: photovoltaic generator; vector control; adaptive fuzzy logic control; PI control; induction motor.

\section{INTRODUCTION}

AC motors supplied by photovoltaic are increasingly used in the rural remote areas of many developing countries for man applications [1-3]. To avoid additional costs, the $\mathrm{AC}$ motors are coupled through DC/AC inverter to the photovoltaic generator without storage batteries. Various studies have been carried out on sizing [4], matching [5,6] and optimizing PV systems [4,7]. DC motors were initially used since they offered easy implementation with cheap power conversion [8,9]. A number of existing operational systems have shown that these schemes suffer from maintenance problems. To overcome these drawbacks, brushless permanent magnet motors have been proposed [2]. However, this solution is limited only for Low power PV systems. The induction motor based PV systems offers an Alternative for a more reliable and maintenance free system [10]. The motor characteristics are severely affected by the PV generator, which was considered as a current generator with dependent voltage source. For such applications, where the PV generators feds an AC motor (PMSM or 
IM), a chopper and/or an inverter should be included in order to perform the DC-AC conversion stage.

\begin{tabular}{|c|c|c|c|}
\hline \multicolumn{4}{|c|}{ NOMENCLATURE } \\
\hline$d, q$ & $\begin{array}{l}\text { axes corresponding to the } \\
\text { synchronous reference frame }\end{array}$ & $r_{s}, r_{r}$ & $\begin{array}{l}\text { stator and rotor resistances } \\
\text { respectively }\end{array}$ \\
\hline$E_{p v}$ & $\begin{array}{l}\text { the average PV array energy } \\
\text { required }\end{array}$ & $T_{d}$ & the daylight period \\
\hline$f$ & friction coefficient & $T_{l}$ & the load torque \\
\hline$i_{d s}, i_{q s}$ & d- and q-axis of stator currents & $\eta_{p v}$ & $\begin{array}{l}\text { the total degradation of the PV } \\
\text { arrays }\end{array}$ \\
\hline$J$ & total inertia & $\eta_{1}$ & $\begin{array}{l}\text { the line losses from PV arrays } \\
\text { to the inverter }\end{array}$ \\
\hline$L_{m}$ & magnetizing inductance & $\lambda_{d r}, \lambda_{q r}$ & $\begin{array}{l}\text { d- and q-axis of rotor leakage } \\
\text { flux }\end{array}$ \\
\hline$L_{s}, L_{r}$ & $\begin{array}{l}\text { stator and rotor self inductances } \\
\text { respectively }\end{array}$ & $v_{d s}, v_{q s}$ & d- and q-axis of stator voltages \\
\hline$P_{d}$ & $\begin{array}{l}\text { the requirements power during } \\
\text { daylight }\end{array}$ & $\omega_{m}$ & angular rotor speed \\
\hline$P_{p v}$ & $\begin{array}{l}\text { the average generated power by } \\
\text { the PV array }\end{array}$ & $\omega_{s}$ & angular synchronous speed \\
\hline
\end{tabular}

The development of the new technologies of semiconductors and converters permits an increase of commutation frequencies and thereby improved energy conversion. In the same way, calculations are considerably decreased, permitting the application of new algorithms of command assuring a decoupling of the flux and the torque in machines to alternating current, in transient and steady-state regime. The field oriented control has been usually applied to the adjustable speed induction motor since the torque and flux linkages are highly coupled with each other so that the complex nonlinear dynamics appears [11-13]. Fast transient response is made possible by decoupled torque and flux control. A conventional PI controller that is robust in terms of speed tracking can be easily designed and implemented according to the choice of the overall closed-loop transfer function. Since in this study, only the stator and rotor equations are used to design controllers. Therefore, these controllers, the flux, current and speed controllers have relatively simple structures.

Artificial Intelligence techniques such as neural networks, fuzzy logic and genetic algorithms are gaining increased interest nowadays. A lot of techniques have been proposed to tune the gains of PI controller based on artificial intelligence techniques: self tuning fuzzy logic technique is one of these methods proposed for the online adaptive tuning of PI controller [14,15]. In such application, the controller gains are online tuned with the variation of system conditions. The advantage of these techniques is that they are model free strategies because they use the human experience for the generation of the tuning law.

In this paper, speed regulation of the induction motor fed directly by PV generator through vectorial command inverter is presented. Two cases can be 
considered when induction motor fed by PV generator. The first case is operating the motor with variable speed that to extract maximum available power from the PV generator [16]. This case is more appropriate for applications don't need constant speed operations and it is not important to track certain reference speed as water pumping systems. The second case is operating the motor to track a reference speed and to decrease the system cost, where this system does not contain storage batteries. This system is needed in some industry applications.

This study presented the second case, where an adaptive-fuzzy PI controller is introduced in speed regulation of induction motor drive fed by photovoltaic generator system. It is proposed that the motor speed is controlled related to reference speed. The motor performance is improved and the torque ripple is minimized using adaptive fuzzy PI controller. The parameters of the PI controller are adjusted online using fuzzy logic techniques. In order to improve the motor drive performance of the adaptive fuzzy PI controller system, an increase in the membership functions was necessary. At the same time the individual set of rules are formed for each $K_{p}$ and $K_{i}$. By using individual set of rules, the controller can be adapted to any change of parameter. Wherever, in fuzzy PI controller only common set of rules are formed for $K_{p}$ and $K_{i}$.

Time-based simulations are carried out to verify the effectiveness of the proposed scheme. The results obtained proved that the proposed adaptive fuzzy PI controller is able to control successfully the IM supplied by PV generator system in the transient and steady state cases. Also, the proposed controller is able to track the reference speed with different values of solar insolation level and variable load torque.

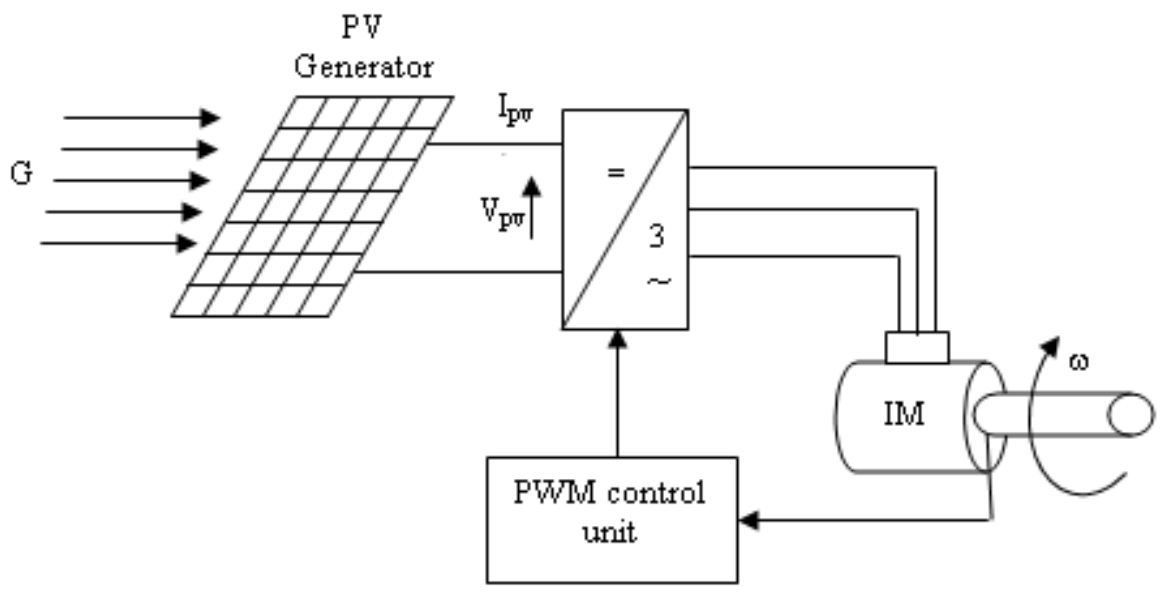

Figure. (1): The proposed PV generator induction motor system

\section{SYSTEM DYNAMIC MODEL}

\subsection{Photovoltaic System}

The proposed induction motor drive system fed by PV generator consists of two stages. The first one is the PV generator and the second one is the vector controlled inverter to regulate the motor speed. 
The specific generated power from PV array depends mainly on the required power by the load, efficiencies of the system components and load operating periods. The average generated power by the PV array can be expressed as follows [17]:

$$
P_{p v}=\frac{T_{d} P_{d}}{\eta_{p v} \eta_{l}}
$$

By determining the PV arrays output power $\left(P_{p v}\right)$ using eq. 1, the total degradation of the PV array $\eta_{p h}$ and the line losses from PV arrays to the inverter $\eta_{l}$, the required area of the solar arrays can be estimated.

\subsection{Model of Photovoltaic Generator}

The PV generator consists of solar cells connected in series and parallel fashion to provide the desired voltage and current required by the inverter induction motor system. This PV generator exhibits a nonlinear voltage-current characteristic that depends on the insulation (solar radiation), as given below [9].

$V_{p v}=\frac{N_{s}}{\Lambda} \ln \left[\frac{G N_{p} I_{p h}-I_{p v}}{N_{p} I_{o}}+1\right]-\frac{N_{s}}{N_{p}} R_{s} I_{p v}$

where

$\Lambda=\frac{q}{\varepsilon Z T}$

Where $V_{p h}$ is the PV generator voltage; $I_{p v}$ is the PV generator current; $\Lambda=q /(\varepsilon \times Z \times U)$, is the solar cell constant; $q=1.602 \times 10^{-19} \mathrm{C}$. is the electron charge; $Z=1.38 \times 10^{-23} \mathrm{~J} / \mathrm{K}$ is Boltzman constant; $T=298.15^{\circ} \mathrm{C}$ is the absolute temperature; $\varepsilon$ $=1.1$ is the completion factor; $N \mathrm{~s}=700$ is the series-connected solar cells; $N_{\mathrm{p}}=11$ is the parallel paths; $R_{s}=0.0152 \Omega$ is the series resistance per cell; $I_{p h}=4.8 \mathrm{~A}$ is the photo current per cell; $I_{o}=2.58 \mathrm{e}^{-5}$ A is the reverse saturation current per cell; $G$ is the solar insulation in per unit, and 1.0 per unit of $G=1000 \mathrm{~W} / \mathrm{m}^{2}$.

\subsection{Induction Motor Model}

The stator and rotor voltage equations of an induction motor in a synchronous reference frame can be expressed as follows [18]:

$$
\begin{aligned}
& \frac{d i_{d s}}{d t}=\frac{1}{\sigma L_{s}}\left[-\left(r_{s}+\frac{L_{m}^{2} r_{r}}{L_{r}^{2}}\right) i_{d s}+\omega_{s} \sigma L_{s} i_{q s}+\frac{L_{m} r_{r}}{L_{r}^{2}} \lambda_{d r}+\frac{L_{m}}{L_{r}} \omega_{m} \lambda_{q r}+v_{d s}\right] \\
& \frac{d i_{q s}}{d t}=\frac{1}{\sigma L_{s}}\left[-\omega_{s} \sigma L_{s} i_{d s}-\left(r_{s}+\frac{L_{m}^{2} r_{r}}{L_{r}^{2}}\right) i_{q s}+\frac{L_{m} r_{r}}{L_{r}^{2}} \lambda_{q r}-\frac{L_{m}}{L_{r}} \omega_{m} \lambda_{d r}+v_{q s}\right] \\
& \frac{d \lambda_{d r}}{d t}=-\frac{r_{r}}{L_{r}} \lambda_{d r}+\left(\omega_{s}-\omega_{m}\right) \lambda_{q r}+\frac{L_{m} r_{r}}{L_{r}} i_{d s} \\
& \frac{d \lambda_{q r}}{d t}=-\frac{r_{r}}{L_{r}} \lambda_{q r}-\left(\omega_{s}-\omega_{m}\right) \lambda_{d r}+\frac{L_{m} r_{r}}{L_{r}} i_{q s}
\end{aligned}
$$


$\frac{d \omega_{m}}{d t}=\frac{1}{J}\left(T_{e}-T_{l}-f \omega_{m}\right)$

Where $T_{e}$ is the electromagnetic torque developed by the motor which can be expressed as:

$$
\begin{aligned}
& T_{e}=\frac{L_{m} P}{L_{r}}\left(\lambda_{d r} i_{q s}-\lambda_{q r} i_{d s}\right) \\
& \sigma=1-\frac{L_{m}^{2}}{L_{s} L_{r}}
\end{aligned}
$$

\section{PRINCIPLE OF ADAPTIVE FUZZY PI CONTROLLER}

The block diagram of the proposed adaptive fuzzy logic PI controller is shown in figure (2). The main objectives of the proposed adaptive fuzzy logic PI controller are to decrease the control scheme complexity and to improve the static and the dynamic performances of the system, especially, for systems whose modeling are complicated or whose parameters are inaccessible. In this case, the adaptive fuzzy controller is designed to adjust the PI parameters $K_{p}$ and $K_{i}$ in order to meet the appropriate required characteristics such as maximum overshoot, rise time, settling time and steady state error. Therefore, fuzzy logic controller will be designed, so that it generates its control signal according to the proportional and integral actions of the PI controller.

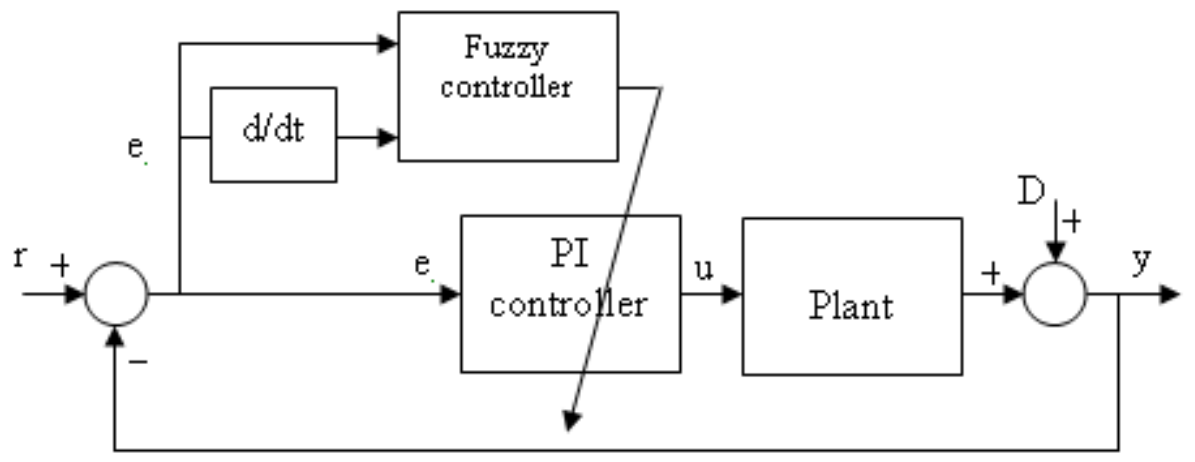

Figure (2): Block diagram of adaptive fuzzy PI controller.

The procedures of the AFPIC system are as follows:

i) identifying the different combinations between the PI parameters, the error $e$ and the change in error $\dot{e}$.

ii) the controller adjusts the PI controller parameters on-line through fuzzy inference so as to meet the different $e$ and $\dot{e}$ to the different requirements of the controller parameters.

\subsection{Design of Adaptive Fuzzy PI Controller}

As we know, mostly PI controller can give good performance only when the controlled system operates at the operating point (the point at which the controller is designed). 
So, the PI controller is often not properly tuned (due to plant parameter variations, operating condition changes or uncertainties), so there is a significant need to develop methods for the automatic tuning of PI controller parameters. Taking into account the differential effect that is not apparent in engineering practice and the good robustness of fuzzy control, fuzzy control theory is used in this study to tune the parameters of the PI controller. The basic formula for the PI controller is:

$u(t)=K_{p} e(t)+K_{i} \int_{0}^{t} e(t) d t$

where $K_{\mathrm{p}}$ is the proportional gain, $K_{\mathrm{i}}$ is the integral gain.

The error $e(n T)=r(n T)-y(n T)$ and change in error $\dot{e}(n T)=[e(n T)-e(n T-T)]$ are considered as inputs to the fuzzy controller. $\Delta K_{p}$ and $\Delta K_{i}$ are chosen as outputs of fuzzy controller to amend the parameters $\mathrm{K}_{\mathrm{P}}$ and $\mathrm{K}_{\mathrm{i}}$ of the PI controller. Then, $K_{p}$ and $K_{i}$ are obtained as following:

$K_{p}=\bar{K}_{p} * \Delta K_{p}$

$K_{i}=\bar{K}_{i} * \Delta K_{i}$

where $\bar{K}_{p}$ and $\bar{K}_{i}$ are the initial values of $\mathrm{K}_{\mathrm{P}}$ and $\mathrm{K}_{\mathrm{i}} \cdot \Delta K_{p}$ and $\Delta K_{i}$ are the fuzzy controller outputs. $\mathrm{K}_{\mathrm{P}}$ and $\mathrm{K}_{\mathrm{i}}$ are the resultant outputs of the PI controller.

The error $e$, the change in error $\dot{e}, \Delta K_{p}$ and $\Delta K_{i}$ are $\{-6,-5,-4,-3,-2,-$ $1,0,1,2,3,4,5,6\}$, the fuzzy subsets are (NB,NM,NS,ZR,PS,PM,PB). Where PB, PM and PS are the abbreviation for positive big, positive medium and positive small; ZR is the abbreviation for zero; NS, NM and NB are the abbreviation for negative small, negative medium, and negative big;. The corresponding membership functions for $e$, $\dot{e}$ are shown in Figure (3) and for $\Delta K_{p}$ and $\Delta K_{i}$ are shown in figure (4).

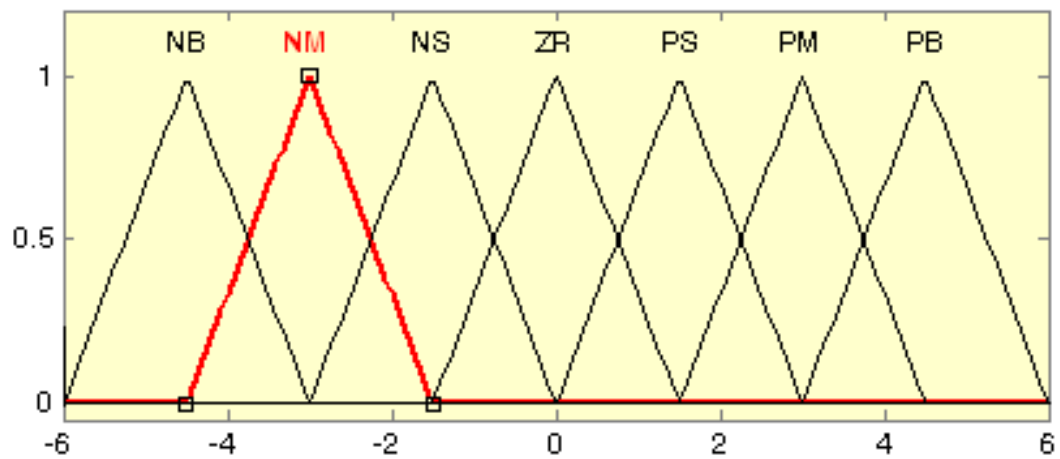

Figure (3): Membership functions for $e, \dot{e}$. 


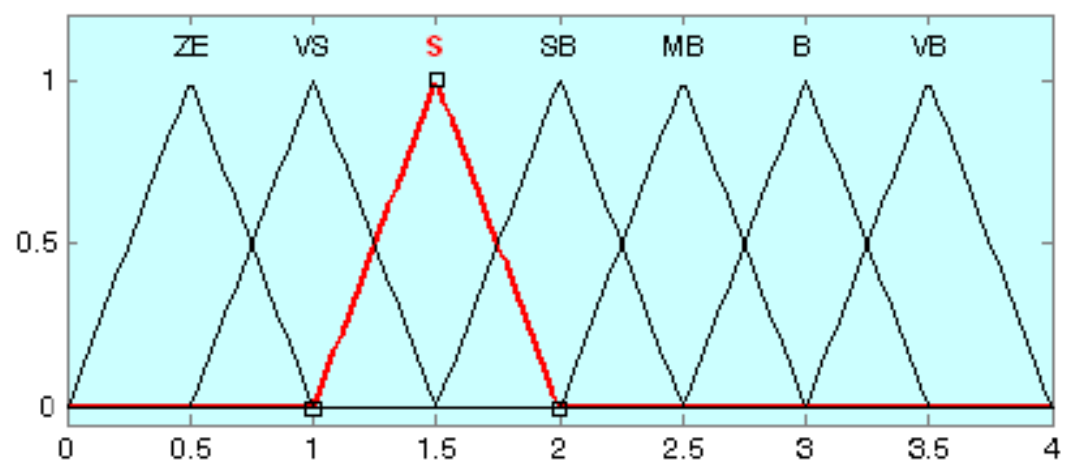

Figure (4): Membership functions for $\Delta K_{p}$ and $\Delta K_{i}$.

\subsection{Rules Design of Adaptive Fuzzy PI controller.}

The system performance requirements have been considered during design adaptive fuzzy rules to tune the PI parameters $\Delta K_{p}$ and $\Delta K_{i}$. Where, if the absolute value of the error $e$ is small, then the great value of $\Delta K_{p}$ and the great value of $\Delta K_{i}$ are considered to guarantee the system stability. If the absolute value of the error $e$ is medium, then the small value of $\Delta K_{p}$ and the adequate value of $\Delta K_{i}$ are considered to improve the performance response in case of decreasing overshoot. If the absolute value of the error $e$ is big, then the great value of $\Delta K_{p}$ and $\Delta K_{i}$ equal zero that to get suitable settling time, suitable rise time and at the same time decrease the overshoot. By the way and by the previous experience, the required fuzzy rules to tune the PI parameters are obtained. These rules in the two tables can be written in the format of IF-THEN as follows:

1. If (e(T) is $\mathrm{PB})$ and $(\dot{e}(T-1)$ is $\mathrm{PB})$ then $\left(\Delta K_{p}(T-1)\right.$ is $\left.\mathrm{NB}\right)$ and $\left(\Delta K_{i}(T-1)\right.$ is $\mathrm{PB})$

2. If (e (T) is $\mathrm{PB})$ and ( $\dot{e}(T-1)$ is $\mathrm{PM})$ then $\left(\Delta K_{p}(T-1)\right.$ is $\left.\mathrm{NB}\right)$ and $\left(\Delta K_{i}(T-1)\right.$ is $\mathrm{PB})$

3. If (e (T) is PB) and ( $\dot{e}(T-1)$ is PS) then $\left(\Delta K_{p}(T-1)\right.$ is NM) and $\left(\Delta K_{i}(T-1)\right.$ is PM)

49. If (e (T) is NB) and ( $\dot{e}(T-1)$ is NB) then $\left(\Delta K_{p}(T-1)\right.$ is PB) and $\left(\Delta K_{i}(T-1)\right.$ is NB)

The above reasoning can be further clarified by looking at Figures. (5) and (6) that depict the fuzzy tuning rules for both the proportional and integral parameters, respectively. 


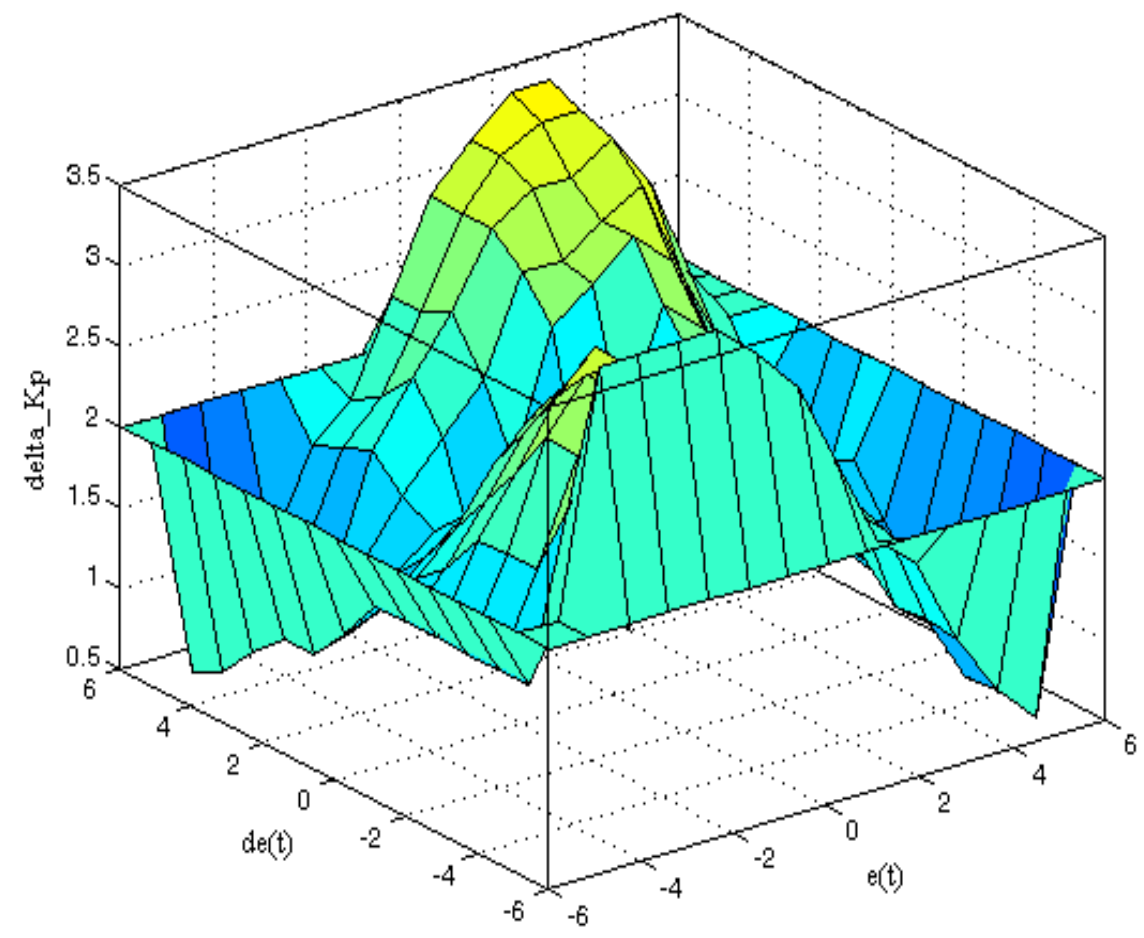

Figure (5): Three dimensional plot for rule base of $\mathrm{K}_{\mathrm{p}}$.

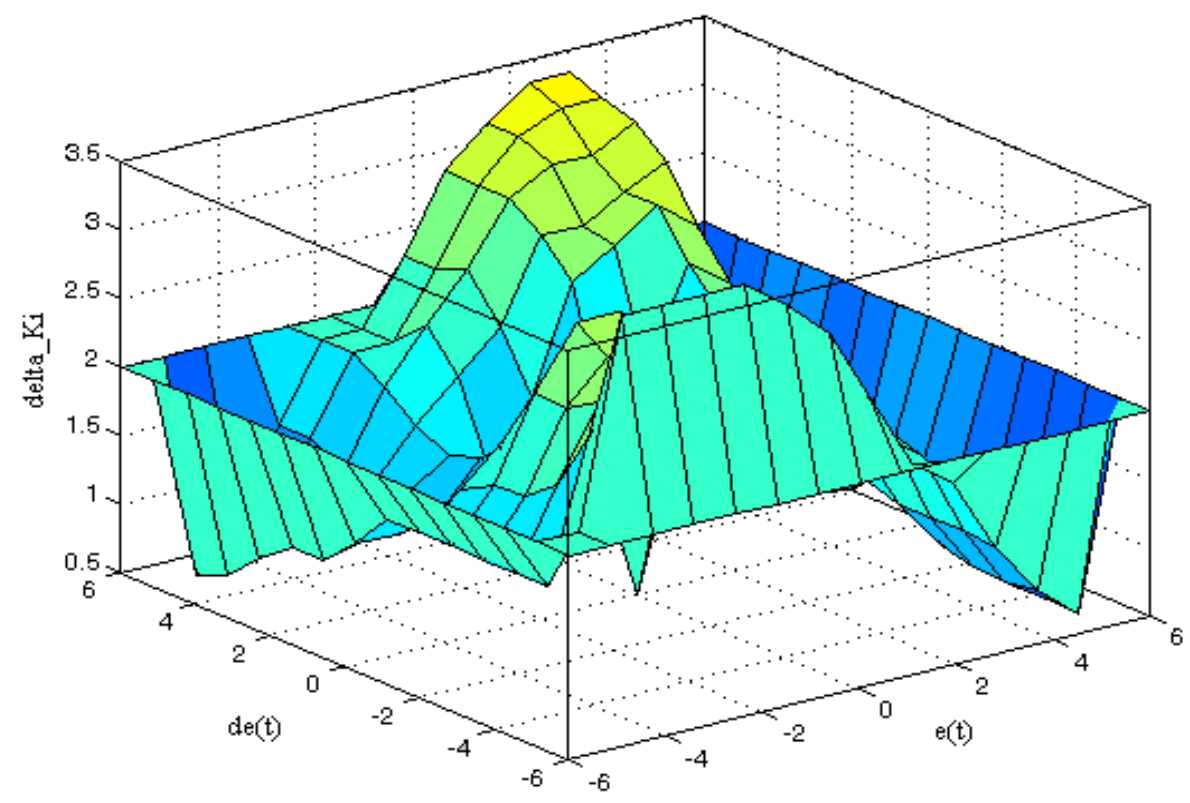

Figure (6): Three dimensional plot for rule base of $K_{i}$ 


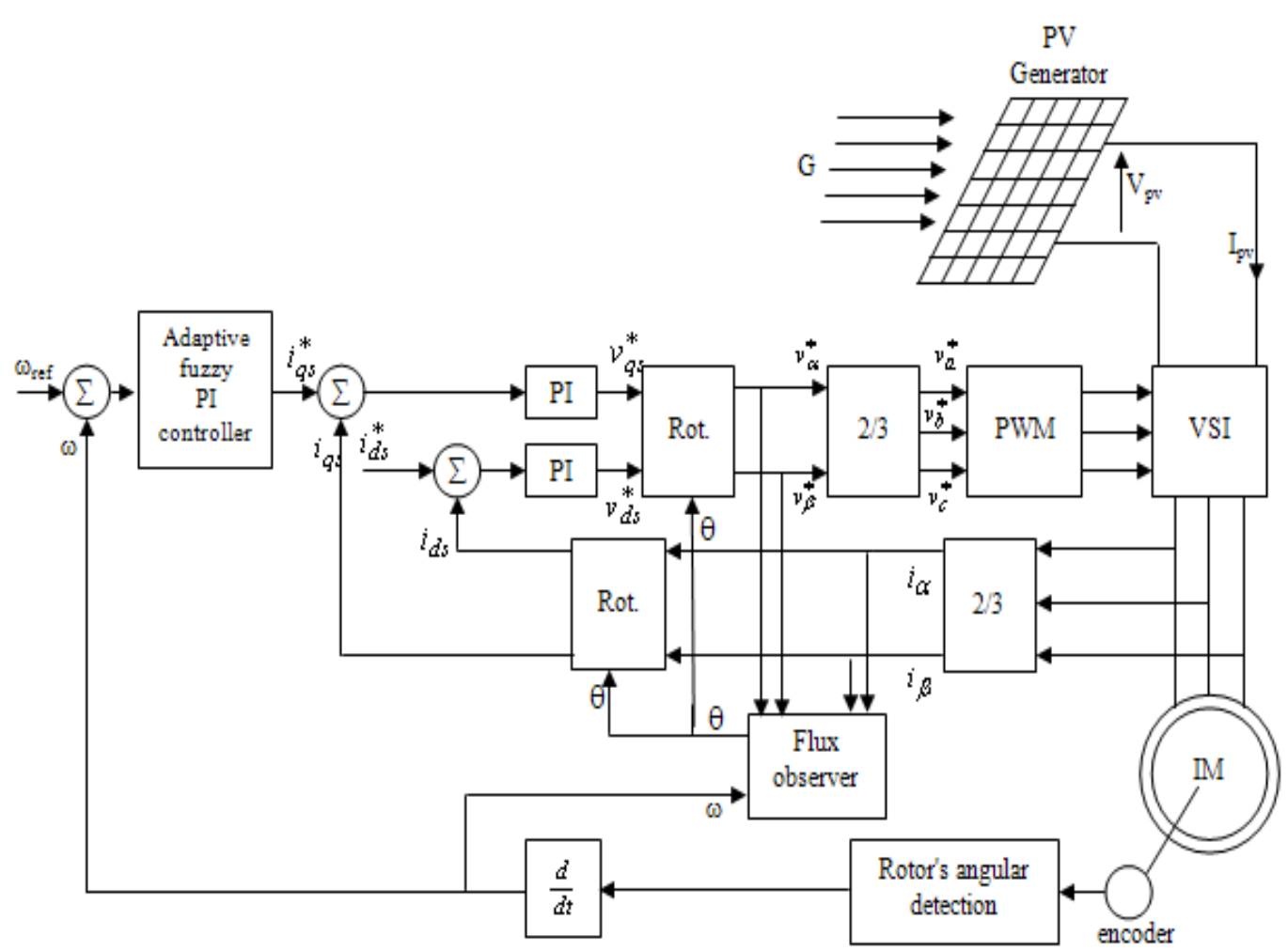

Figure (7): block diagram of the proposed PV generator-induction motor speed control system

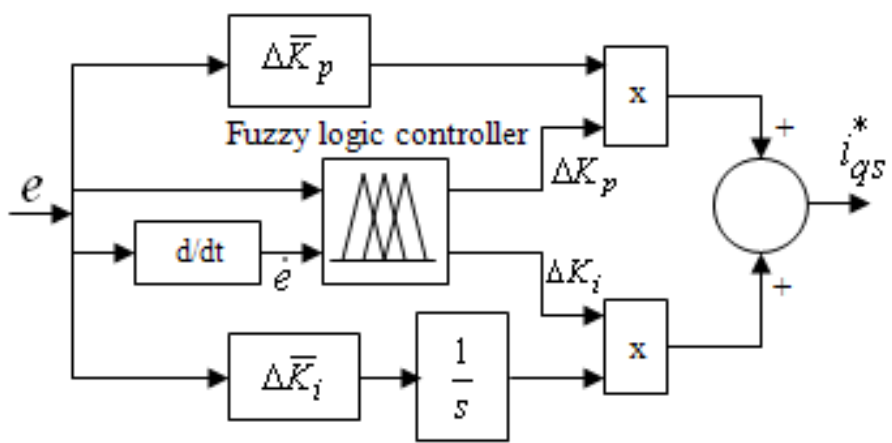

Figure (8): block diagram of the proposed adaptive fuzzy PI controller subsystem

\section{SIMULATION RESULTS}

Digital simulations have been carried out in order to validate the effectiveness of the proposed scheme. The simulation tests are carried out using Matlab/Simulink software package [19]. Wherever, induction motor is represented in MATLAB/SIMULINK using equs. (4-9). also, the fuzzy membership controller is designed using the rules in section 3.2 .

In the proposed system under study, the initial values of the PI parameters are chosen such that $\bar{K}_{p}=1.5$ and $\bar{K}_{i}=0.8$. The proposed PV generator-IM system with 
the proposed controller is shown in figure (7). the block diagram of the proposed adaptive fuzzy PI controller is shown in figure (8). The following simulation tests are carried out to show the validity of the proposed adaptive fuzzy PI controller.

\subsection{Variable Speed Case}

It is assumed that the machine follows a certain speed trajectory starting from 200 $\mathrm{rad} / \mathrm{sec}$., stepped to low speed value $10 \mathrm{rad} / \mathrm{sec}$., at time $\mathrm{t}=0.06 \mathrm{sec}$., and the insolation level is varied as shown in figure (9). The load torque is kept constant at the value 3.5 N.m during the simulation period. Figure (9)., shows the dynamic responses of the PV generator output voltage, rotor speed, torque, stator voltages and stator currents of the induction motor based on adaptive fuzzy PI controller. This figure shows also that because the insolation level is not constant and it is varied with time (figure 9a), the PV output voltage is not constant too (figure $9 \mathrm{~b}$ ) and hence the stator amplitude voltage is not constant too (figure 9c). Although the PV generator output voltage is not constant, the proposed adaptive fuzzy PI controller comes in action to terack the motor rotor speed with the reference values with small overshoot and small settling time as shown in figure (9d). Figure (9e) and figure (9f) show the stator currents and torque response based on the proposed controller. These figures show that the stator current and the torque have less ripple content and over shoot through very short simulation time $(0.1$ second).

Figure (9d) shows also that the performance of the induction motor with the proposed controller is investigated at low speed $(10 \mathrm{rad} / \mathrm{sec}$.). In case of low speed, the induction motor performance with the proposed controller is adequate as regard to small settling time, small overshoot and ripple minimization as shown in figure (9).

Figures (10) and (11) show the rotor speed and torque responses based on the proposed adaptive fuzzy PI controller and the classical PI controller. It is obvious from these figures that with the AFPI controllers, the obtained dynamic response of IM using AFPI controller has less overshoot, less settling time and better response at load changes than using PI controller.

\subsection{Variable Torque Case:}

The performance of the induction motor with the proposed adaptive fuzzy PI controller is investigated during load torque step variations. The load torque is assumed to be stepped from 3.5 N.m. to 7 N.m. at time $t=0.06$ second. Figure (12) shows the system responses using the adaptive fuzzy PI controller. It is clear that the system has good transient response. Also, the ripples are minimized in the torque response. 

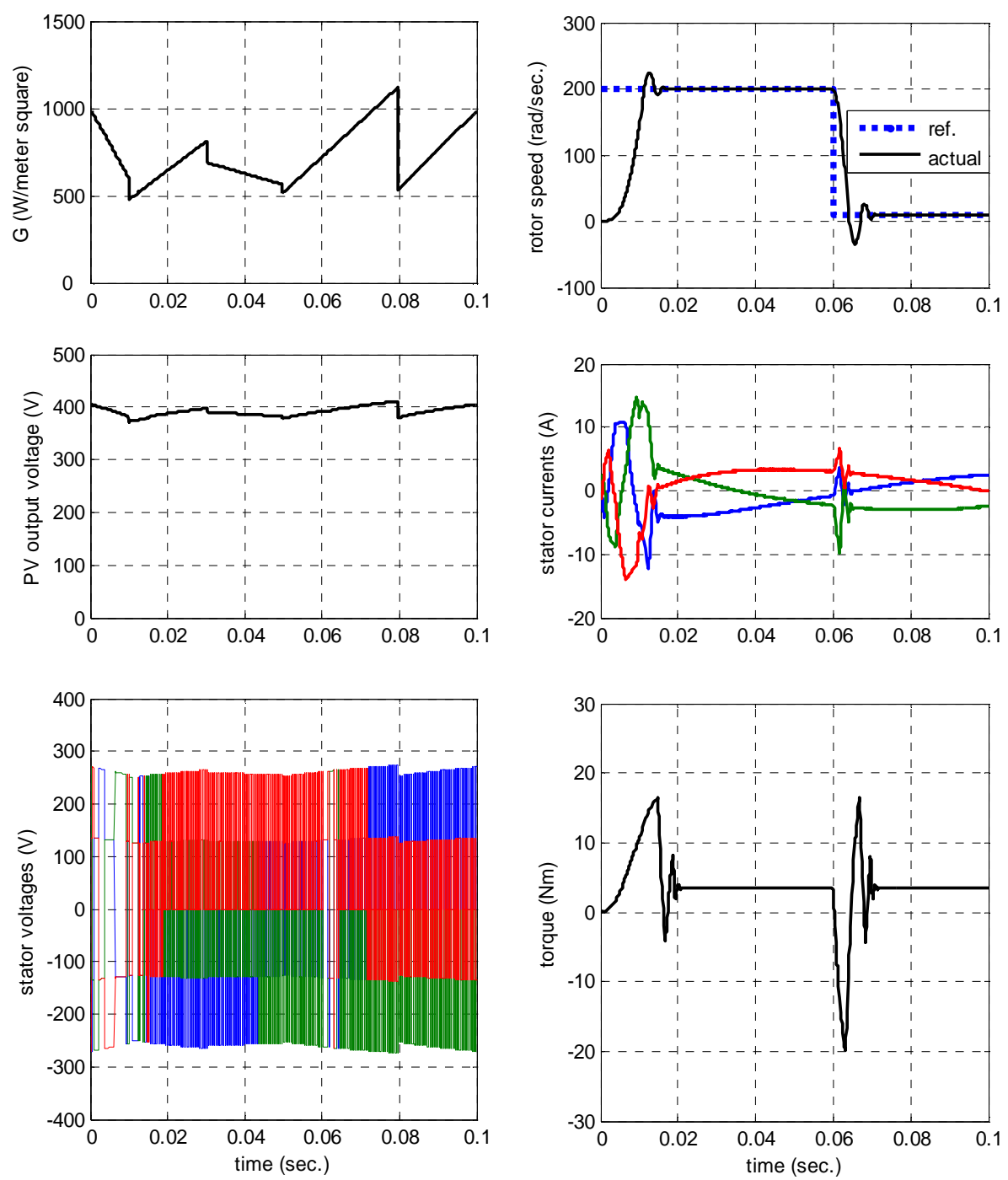

Figure (9): The PV generator-induction motor system response based on adaptive fuzzy PI controller: with reference speed variations. 


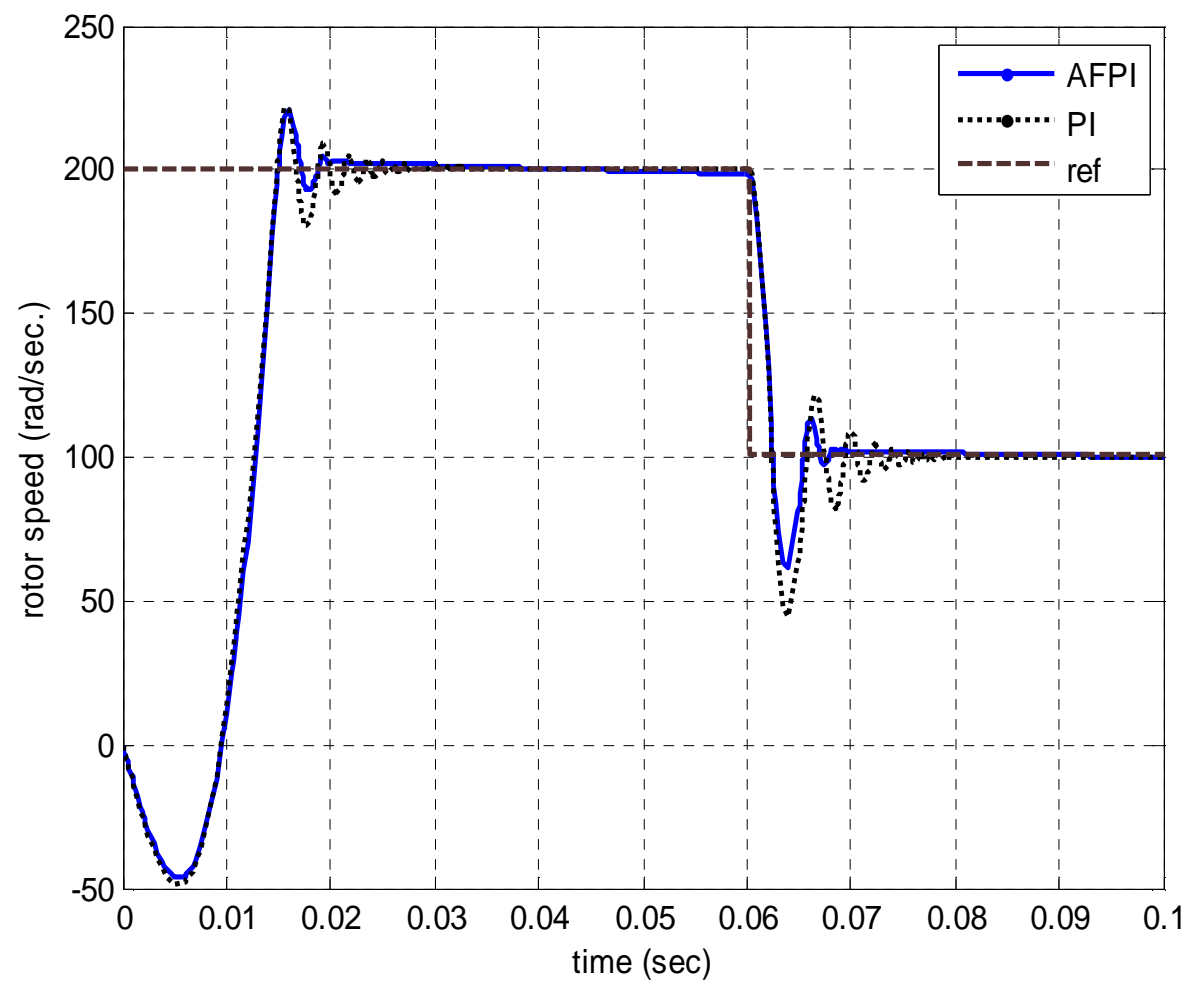

Figure (10): Rotor speed response based on the proposed adaptive fuzzy PI controller and conventional PI controller.

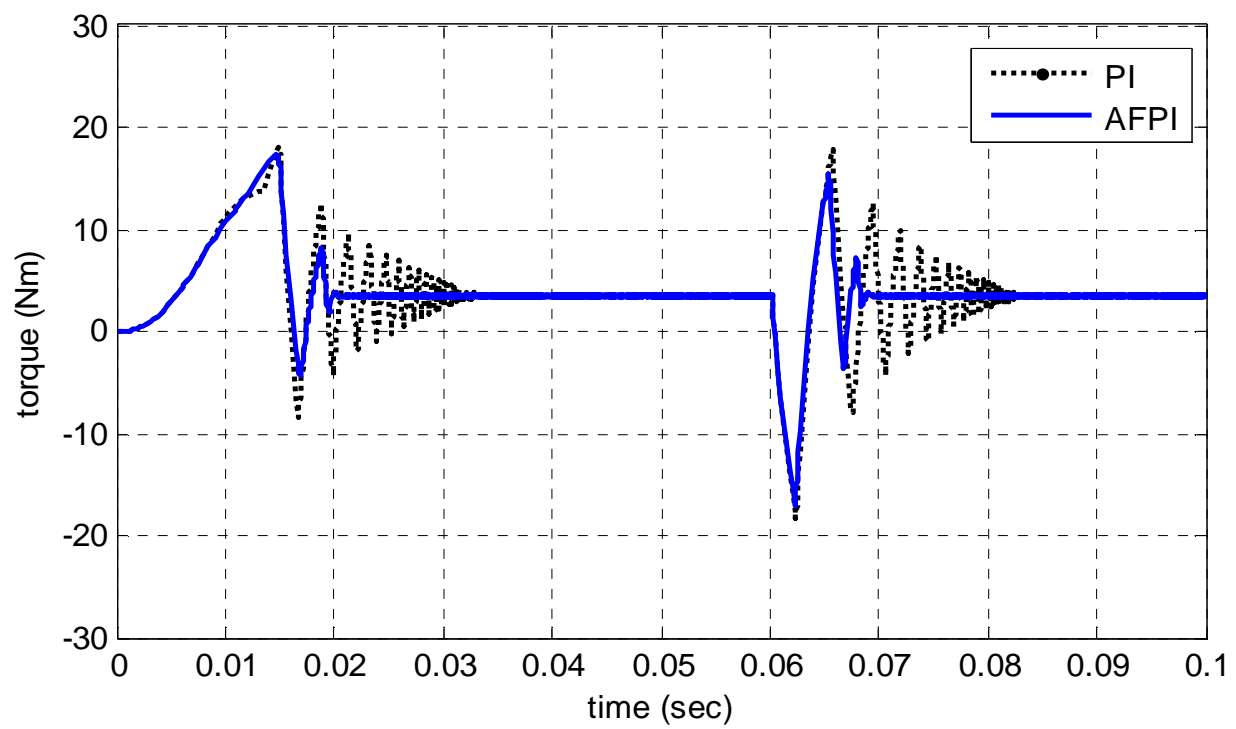

Figure (11): Torque response based on the proposed adaptive fuzzy PI controller and conventional PI controller. 

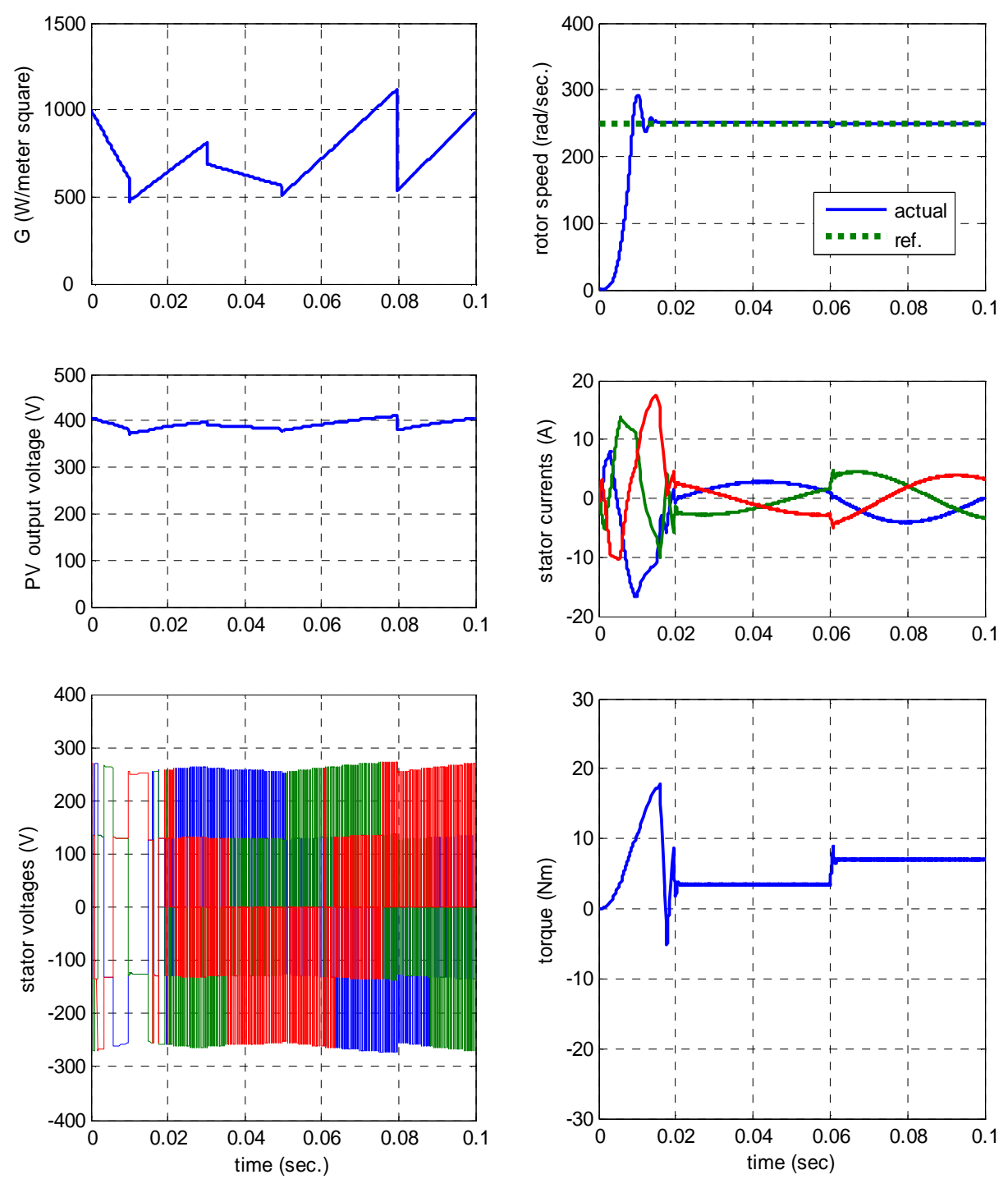

Figure (12): The PV generator-induction motor system response based on adaptive fuzzy PI controller: with reference load torque variations

\section{CONCLUSION}

This study presented speed control of induction motor fed directly through voltage source inverter by PV generator. It is proposed that to decrease the system cost and eliminates maintenance problems, the system does not include storage batteries and the PV generator output voltage is varied with variations of the insolation level and hence, there is no need for DC/DC converter.

The main goal of this study was to design a controller that enables the speed of the induction motor fed from the PV generator to track certain reference values with variations of both PV generator output voltage and the load torque. To reach this goal, a controller was designed based on adaptive fuzzy logic PI controller and the field 
oriented control. Fast transient response is made by decoupled torque and flux control. Also in this study, the flux, current and speed controllers have relatively simple structures because only the stator and rotor equations are used to design controllers. The results show that the speed tracker is achieved with zero steady state error and with very small settling time less than ten millisecond and accurate tracking performance of the proposed system has been achieved. Moreover, the proposed controller has significantly better performance relative to PI controller especially at load change conditions.

\section{REFERENCES}

[1] Messaoud Makhlouf, Feyrouz Messai and Hocine Benalla, "vectorial command of induction motor pumping system supplied by a photovoltaic generator". Journal of electrical engineering, 62(1), 2011, p. 3-10.

[2] SWAMY, C. L. P. et al, "Dynamic performance of a permanent magnet DC motor powered by a PV array for water pumping". Solar Energy Mat Solar Cell, 36, 1995, p. 187-200.

[3] BETKA, A.-MOUSSI, A., "performance optimization of a photovoltaic induction motor pumping system, Renewable Energy, 29, 2004, p. 2167-2181.

[4] SHRERTHA, G. B.-GOEL, L., "a study on optimal sizing of stand alone photovoltaic stations". IEEE Trans. on Energy Conv., 13(4), 1998, p. 373-377.

[5] Akbaba M, et al., "Matching of separately excited DC motors to photovoltaic generators for maximum power output". Solar Energy, 63(6), 1998, p. 375-385.

[6] Saied MM., "Matching of DC motor to photovoltaic generator for maximum daily gross mechanical energy". IEEE Trans. on Energy Conv., 3(3), 1988, p. 465-471.

[7] SAMIN, J. et al, "Optimal sizing of photovoltaic in varied climates". Solar Energy, 6(2), 1997, p. 97-107.

[8] APPELBAUM, J., "Starting and steady state characteristics of DC motor powered by solar Cell generator". IEEE Trans. on Energy Conv., 1(1), 1986, p. 17-25.

[9] Ahmed M. Kassem, "modeling, analysis and neural MPPT control design of a PVgenerator powered DC motor-pump system". International journal of electrical power and energy systems, in press.

[10] BAHT, S. R. et al., "Performance optimisation of induction motor-pump using photovoltaic energy source". IEEE Trans. on Ind. App., 23(6), 1987, p. 995-1000.

[11] Mimouni MF, Dhifaoui R, Brudny JF, Roger D., "Field-oriented control of double-star induction machine". Int J System Analysis Modelling Simulation (SAMS), 37, 2000, p. 181-202.

[12] Mimouni MF, Messaoud H, Dhifaoui R, Brudny JF, Roger D. Kalman filter for indirect adaptive control of double-star induction machine. Int J System Analysis Modelling Simulation (SAMS), 37, 2000, p. 513-33.

[13] Wasynezuk O, Anwah MA., "Modelling and dynamic performance of a self commutated photovoltaic inverter system". IEEE Trans. on Energy Conv., 4(3), 1989.

[14] Mudi Rajani K, Pal Nikhil R., "A robust self-tuning scheme for PI-and PD-type fuzzy controllers". IEEE Trans. on Fuzzy Systems, 7(1), 1999, p. 2-16.

[15] Mudi Rajani K, Pal Nikhil R., "A self-tuning fuzzy PI controller". Fuzzy Sets and Systems, 115(2), 2000, p.327-338 
[16] Nafeh AbdEl-ShafyA, Fahmy FH, Abou El-Zahab EM., "Maximum-power operation of a stand alone PV system using fuzzy logic control". Int J Numerical Modelling Electronic Networks Devices Fields, 15, 2002, p. 385-98.

[17] Yousry Atia, "torque ripple minimization for induction motor driven by a photovoltaic inverter". Journal of power electronics, 9(5), 2009, p. 679-690.

[18] M. Arrouf and N. Bouguechal, "Vector control of an induction motor fed by a photovoltaic generator". Applied Energy, 74 (2003), p. 159-167

[19] "MATLAB Math Library User's Guide", by the Math Works. Inc., 2010.

\section{استخدام الحاكم الضبابي للضبط الأاتي لمعاملات حاكم تناسبي تكاملي لتحسين أداء محرك حثي مغذي من مولا ضوئي}

يقدم هذا البحث التحكم في سرعة محرك كهربي حثي مغذب مباشرة من وحدة توليد ضوئية photovoltaic (PI) تم ضبط معاملاته ذاتيا باستخدام الحاكم الضبابي (fuzzy logic controller). حتى ينم استخلاص الطاقة العظمي من المولد الضوئي وفي نفس الوقت

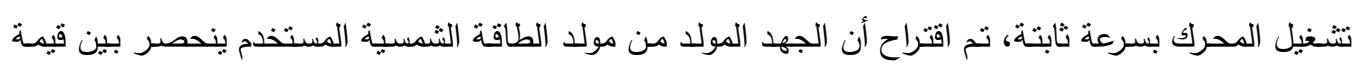
عظمي وقيمة صغري تبعا لتغير أثنعة الثمس بدلا من تثغيل المحرك عند جهد ثابت. حيث ذلك يقلل من تكلفة

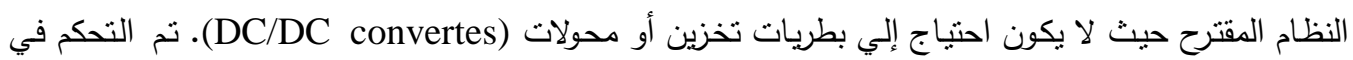

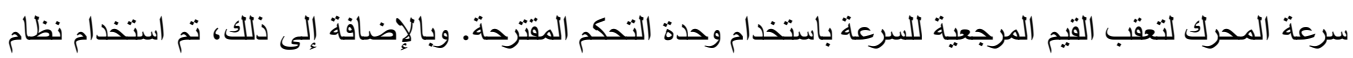

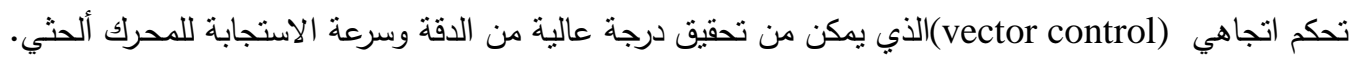

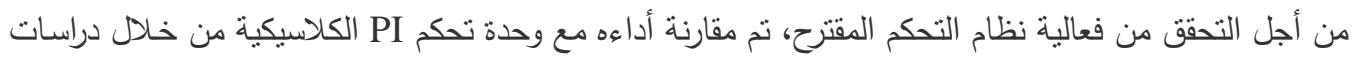
المحاكاة. تظهر النتائج التي تم الحصول عليها أن الحاكم المقترح بمكن من التنغيل الأمثل للمحرك ألحثي. 